\title{
REVIEW
}

\section{Species composition and geographic distribution of invertebrates in fouling communities along the east coast of the USA: a regional perspective}

\author{
Ronald H. Karlson ${ }^{1,3, *}$, Richard W. Osman ${ }^{2}$ \\ ${ }^{1}$ Department of Biological Sciences, University of Delaware, Newark, Delaware 19716, USA \\ ${ }^{2}$ Smithsonian Environmental Research Center, PO Box 28, 647 Contees Wharf Road, Edgewater, Maryland 21037, USA
}

${ }^{3}$ Present address: 266 Carters Mill Road, Elkton, Maryland 21921, USA

\begin{abstract}
In recognition of increasing coastal development, warming seas, species invasions, and numerous systematic revisions, we have reviewed the fouling community literature to update the species composition and geographic distributions exhibited by this fauna along the east coast of the USA. We found 1443 records for 317 species. The Bryozoa were the most prevalent phylum in terms of numbers of records and species, but 2 invasive ascidians were the most frequently reported species. Among all species, $9.1 \%$ of the fauna have been reported to be invasive. Most species were represented by only 1 to 3 records, suggesting that this fauna has been underrepresented in the literature. The number of species estimated per state peaked in Florida, North Carolina, and Massachusetts, where provincial faunas overlap. Although Cape Cod in Massachusetts and Cape Hatteras in North Carolina represent putative faunal boundaries along the east coast, $63 \%$ of the fouling organisms have distributional limits which extend well beyond one or both of these capes. A large proportion of this fauna is widely distributed from New England to the South Atlantic Bight, yet 22 northern species and 96 southern species have restricted distributions. Analysis of community-level studies also revealed regional differences, especially between New England and southern states. These patterns are indicative of latitudinal variation and the transitional nature of this fauna. Given the strong representation of subtropical/tropical species and the prospects for continued warming of the ocean, we anticipate more species invasions and northward extensions of warm-water species along much of the east coast.
\end{abstract}

KEY WORDS: Species composition · Invasions $\cdot$ Range extensions $\cdot$ Systematic revisions

Resale or republication not permitted without written consent of the publisher

\section{INTRODUCTION}

In recent years, we have begun to recognize significant mesoscale patterns in the structure of species assemblages in the sea (e.g. Kritzer \& Sale 2006, Witman \& Roy 2009). This emerging perspective began largely with metapopulation and macroecological studies in terrestrial systems. Some believe the application of the metapopulation concept to marine sys- tems represents 'the most important milestone of marine ecology in more than 50 years' (Roughgarden 2006). Previously, many ecological studies in the sea were conducted only at local spatial scales. For example, we note our own community studies from 35 yr ago (Osman 1977, Sutherland \& Karlson 1977, Karlson 1978). More recently, community ecologists emphasize using both local and much broader spatiotemporal scales (Cornell \& Lawton 1992, Ricklefs \& 
Schluter 1993) in order to address broad-scale patterns and the dispersal processes linking local communities with the regional species pool.

Here we focus on the assemblage of invertebrate species comprising marine fouling communities along the east coast of the USA. These organisms occur on artificial substrates and are typically widespread. Early studies of this fauna were mostly conducted at a few sites (e.g. Woods Hole, Massachusetts and Beaufort, North Carolina) and many of these were focused only on the more abundant species. Consequently, there were many gaps in our knowledge of the distribution and abundance patterns of this fauna. In more recent years, a broader range of study sites and increased sampling effort for selected taxa has improved the quality of this information.

Currently, this fauna is changing due to a number of factors. Worldwide coastal development is increasing the available substrate (Bulleri \& Chapman 2010). Global climate changes are warming the temperate waters on both the east and west coast of the USA and altering distribution and abundance patterns (e.g. Stachowicz et al. 2002, Jones et al. 2009, Sorte et al. 2010, Sorte \& Stachowicz 2011). These changes, along with shipping-related activities (direct transport on ship hulls, release of ballast water) and hitchhiking with oyster introductions, contribute to a growing number of species invasions (e.g. Ruiz et al. 1999, 2000, Winston 2009). In recognition of the above changes and recent advances in the taxonomic nomenclature used to describe this fauna, we perceived the need to review the literature and update the current status of fouling communities along the east coast. Here we take a regional perspective in this endeavor.

Along the east coast, temperature variation is highly seasonal, especially at mid-latitudes. At the extreme, annual water temperatures vary by approximately $30^{\circ} \mathrm{C}$ in North Carolina (Sutherland \& Karlson 1977, Coles \& Musick 2000). Larval recruitment and the abundance of many species there vary seasonally (e.g. Ectopleura crocea flourishes in the spring and fall while Pennaria disticha does so in the summer; Sutherland \& Karlson 1977). Other species (e.g. Hydractinia sp. and Xestospongia halichondrioides) recruit slowly and are long-lived (Karlson 1978). Much further south in the Florida Keys, seasonal variation in temperature is less extreme (21 to $31^{\circ} \mathrm{C}$ ) and the warm water in the winter favors more long-lived invertebrates such as corals (Soto et al. 2011). To the north at Woods Hole, Massachusetts, water temperatures are lower, ranging from near zero to $24^{\circ} \mathrm{C}$ (Osman 1977, Nixon et al. 2004) and lar- val recruitment is highly seasonal (Osman 1977, 1978). Thus, temperature along this coast is an important environmental parameter influencing larval recruitment and abundance patterns in fouling communities (see Engle \& Summers 1999 for an analysis linking temperature and latitudinal variation in largely infaunal, estuarine benthic communities from Florida to Massachusetts).

In their analysis of 295 sites, Engle \& Summers (1999) emphasized temperature, but also highlighted variation in the salinity regimes experienced by estuarine benthic invertebrates. We include this information here because it nicely covers the salinity regimes experienced by inshore fouling species along the east coast. The full range of variation included marine, polyhaline (18 to 35 ), high and low mesohaline (12 to 18 and 5 to 12 , respectively), oligohaline ( 0.5 to 5 ), and tidal freshwater (0 to 0.5 ) locations, but most of the variation in the benthic fauna was attributed to the simple distinction between low $(<12)$ and high salinities $(>12)$. South of latitude $35^{\circ} \mathrm{N}$, predominantly high salinity locations were located from Florida to southern North Carolina south of Pimlico Sound. Engle \& Summers (1999) report mean salinities of 23.5 to 27.5 for these southern locations. Rainfall during hurricanes is a major source of freshwater to these environments (see Sutherland \& Karlson 1977). Northward riverine influences on salinity increase in Pimlico Sound and the Chesapeake Bay (mean salinity: $22.4 \mathrm{ppt}$ ), where a full range of salinity regimes occur (Engle \& Summer 1999). The lowest mean salinity was reported for estuarine locations between Cape May, New Jersey, and Cape Cod, Massachusetts (15.4).

The coastal waters between Cape Cod in Massachusetts and Cape Hatteras in North Carolina have long been known as transitional between the stable, cold water to the north and the stable, warm water to the south (Cerame-Vivas \& Gray 1966, Gosner 1971, Engle \& Summers 1999). The water circulation from Labrador to the Florida Keys is dynamic, variable, and quite unusual because of the proximity of polar and subtropical water along this coast (Longhurst 2007). In the winter, the North Wall of the Gulf Stream is only about $300 \mathrm{~km}$ from the pack ice of the Gulf of St. Lawrence. However, the strength and location of westerly winds in the winter are strongly driven by the North Atlantic Oscillation (NAO), and these winds influence the displacement of the Gulf Stream offshore, and the strength of the equatorward flow of the Labrador Current (Longhurst 2007). Mean flows vary substantially along the east coast as follows: at Newfoundland, the total southward trans- 
port of the Labrador Current over the shelf and slope is 0.8 and 5.7 Sverdrups, respectively (Longhurst 2007). The total transport over the shelf drops predictably to 0.4 Sverdrups off Cape Cod, 0.2 Sverdrups off New Jersey, and 0.03 Sverdrups off Cape Hatteras (Loder et al. 1998). The much larger Gulf Stream transport increases northward from 30 Sverdrups in the Straits of Florida to 63 Sverdrups off Cape Hatteras and 150 Sverdrups off the Newfoundland shelf (Richardson \& Knauss 1971, Hogg 1992).

There are several distinguishing features in the coastal oceanography of waters north and south of Cape Hatteras. North of Cape Hatteras, a meandering southward coastal flow over the shelf is characteristic throughout the year (Longhurst 2007). Stratification of shelf waters is complicated by the direction of sustained winds and the influence of tidal streams. Sustained northerlies result in stratification, but sustained southerlies destratify the water. Sustained longshore winds, especially north of Cape Cod, result in upwelling and generally colder water than south of Cape Cod. 'In the Middle Atlantic Bight, tidal fronts parallel the coast and separate an inner neritic from an outer open shelf zone' (Longhurst 2007). South of Cape Hatteras in the South Atlantic Bight, water circulation is less well characterized by mean flows than are shelf flows to the north (Boicourt et al. 1998). Water stratification generally depends on the prevalent wind direction in the spring (Longhurst 2007). The plume of light water from the Chesapeake Bay moves southward, but varies in extent between being close to shore or spread over the entire shelf. It is separated from slope water by a coastal front over the shallow shelf. In general, this water 'is permanently stratified except when disrupted by energetic frontal eddies' bringing slope water from the Gulf Stream across the shelf (Longhurst 2007) or when mixing occurs at the end of the summer with the onset of cooler weather. These frontal eddies are a dominant feature of shelf circulation in the South Atlantic Bight (Boicourt et al. 1998).

These major oceanographic differences between the Northeast Shelf and the South Atlantic Bight are likely to control species distributions along the east coast. North of Cape Hatteras, the opposing Labrador Current and the Gulf Stream produce a gradual north to south change in water temperatures, except for the more abrupt shift to cold water at Cape Cod and the Gulf of Maine. South of Cape Hatteras, oceanographic conditions would appear to favor more unpredictable episodic events influencing larval transport, but the shift from a temperate to a tropical climate must also be considered. For example,
Mytilus edulis is well known in fouling communities in New England and the Mid-Atlantic Bight, but occasional recruitment onto substrates south of Cape Hatteras extends its distribution into the South Atlantic Bight (Wells \& Gray 1960). Ruppert \& Fox (1988) noted that mussels south of North Carolina are typically 'small stunted individuals' and these usually die due to high summer temperatures. In fact, Jones et al. (2009) recently concluded that the thermal limit of this species is, indeed, in the vicinity of Cape Hatteras and it 'is shifting poleward in a manner indicative of global warming'. Comparable shifts may also occur among warm-water species as they reach their cold tolerance limits.

The invertebrates of the northwest Atlantic coast have traditionally been divided into the American Atlantic Boreal Region from Cape Cod to the coast of Labrador and the American Atlantic Temperate Region from Cape Cod to southern Florida. Gosner (1971) noted that there are few endemic species in this latter region and that the tropical Atlantic 'is faunistically the most important contributor to the temperate region'. Within this region, Cape Hatteras has also been recognized as a faunal boundary between the Virginian Province to the north and the Carolinian Province to the south (Cerame-Vivas \& Gray 1966, Gosner 1971).

More recently, Longhurst (2007) used an oceanographic perspective emphasizing the physical forcing of water motion and stratification over the continental shelf to partition the Northwest Atlantic Shelves Province from Labrador to the Florida Keys into 4 'compartments': (1) Newfoundland shelf, (2) Gulf of St. Lawrence, (3) Northeast shelf and Gulf of Maine from Cabot Strait (between Newfoundland and Nova Scotia) to Cape Hatteras, and (4) South Atlantic Bight from Cape Hatteras to the Florida Keys. In so doing, the invertebrate fauna along the east coast of the USA is simply divided at Cape Hatteras.

\section{METHODS}

It is important to note that we have confined our analyses to studies of invertebrates that reported attachment to or fouling of man-made artificial structures (including experimental substrates) or that reported species present on such structures. This epifaunal invertebrate community also occurs on many natural substrates such as rocks, macroalgae, seagrasses, and other invertebrates. We have not included studies of those substrates and thus the species included in this study are a subset of the epifaunal 
invertebrates found along the coast. We began our review by searching the published literature through 2009 for reports of invertebrate species occurring in fouling communities along the east coast of the USA. We used the Thomson Reuters Science Citation Index Expanded database and various keyword combinations with 'fouling' and the names of individual states for this search. A single record for each species in a publication included the genus and species, the state(s) where each study was conducted, and notes on distributional range, systematics, and substrate type. We restricted this analysis to sessile invertebrates (e.g. sponges, hydroids, anthozoans, tubedwelling annelids, barnacles, entoprocts, bryozoans, ascidians), and a few semi-sessile species such as some bivalves reported by a few authors. It has been estimated that these fouling community organisms comprise approximately $2 \%$ of the entire invertebrate fauna (Woods Hole Oceanographic Institution 1952). This rough approximation emphasizes the point that only a small percentage of invertebrates occur in fouling communities. However, much more systematic research is needed to yield better estimates of the total number of species. Mora et al. (2011) recently estimated that $92 \%$ of all animal species in the ocean have yet to be described.

Some of our earliest records are from faunal surveys conducted in the vicinity of Woods Hole, Massachusetts (e.g. Verrill \& Smith 1874, Nutting 1901, Hargitt 1908, Osburn 1910, Sumner et al. 1911, 1913). More recent records come from other faunal surveys, ecological studies, systematic publications, and invertebrate keys on selected taxa. We report our sources in Tables $1 \& 2$ in the main text and in Tables $\mathrm{S} 1$ \& $\mathrm{S} 2$ in the supplement at www. int-res.com/articles/suppl/m458p255_supp.pdf. We attempted to include records from all the ecological studies conducted from Florida to Maine. These ecological sources include all of the published studies cited in Woods Hole Oceanographic Institution (1952), thus covering the early literature well.

Over the years, numerous changes in the taxonomic nomenclature covering this fauna have made it necessary for us to establish a temporal baseline with currently accepted names matched with the published genus and species in our records. To accomplish this, we consulted several primary resources. Firstly, we used the World Register of Marine Species (WORMS, www.marinespecies.org). This website provided currently accepted names for most species along with some recent name changes and distributional information. It also is linked to other systematic websites (e.g. Integrated Taxonomic Information Sys- tem [ITIS], www.itis.gov) and to distributional data on the Ocean Biogeographic Information System (OBIS, www.iobis.org). For many tropical species, we crosschecked these names with the recent comprehensive work on species in the Gulf of Mexico (Felder \& Camp 2009). Secondly, we consulted systematic publications and invertebrate keys covering our geographic area of interest (e.g. Smith 1964, Weiss 1995, Pollock 1998, Martinez 2010) or the specific taxa covered in our survey (e.g. Fraser 1944, Van Name 1945, de Laubenfels 1949, Wells et al. 1960, Maturo \& Schopf 1968, Cairns et al. 2002, Winston 2005). This latter group includes some studies from other geographic locations (e.g. Brazil, Costa Rica, and Pana$\mathrm{ma})$, but these also cover systematic revisions involving some east coast species. Thirdly, we consulted several individuals with considerable experience with selected taxa in order to include some recent systematic revisions or to resolve some particularly problematical taxa (see Acknowledgements). All these resources allowed us to infer northern and southern distributional limits for each species and to estimate the number of fouling species in each state based on the assumption that each species occupied all states over the range between these limits.

To test for any spatial or temporal community-level variation, we conducted similarity and nonmetric multidimensional scaling analyses (Primer 6: ANOSIM, MDS). These analyses used species presence/ absence data generated from species lists for each of the studies. The Bray-Curtis dissimilarity index was used to quantify differences in species composition among studies and regions. Studies were initially classified by state and date of publication, and were further separated by period of publication and between native and invasive species. Period designations were based on publication date as Early (1948 or earlier), Mid (1949 to 1982), and Recent (1983 to 2009). These temporal divisions were nominally 1950 and 1980, but adjusted slightly to be within large gaps in the times between studies. For studies that included data from multiple states, we created a separate species list for each state. These analyses were limited to studies covering at least 3 phyla. This was done to emphasize the community-level studies in the literature and to reduce possible biases that might result from inclusion of studies focused on a single species or phylum. As Massachusetts spanned the biogeographic barrier of Cape Cod and North Carolina spanned the barrier of Cape Hatteras, we classified studies in those states as North and South of their respective barrier. Finally, states were assigned to 7 broader biogeographic regions: (1) Maine, New 
Hampshire, and northern Massachusetts designated as Northern New England, (2) southern Massachusetts, Rhode Island, and Connecticut as Southern New England, (3) New York, New Jersey, Delaware, and Maryland as Northern Mid-Atlantic, (4) Virginia and northern North Carolina as Southern Mid-Atlantic, (5) southern North Carolina as North Carolina, (6) South Carolina and Georgia as the South Atlantic Bight, and (7) Florida. This pooling allowed increased replication for each region and reduced biases resulting from the disproportionate number of studies conducted in the different states.

\section{RESULTS}

Our survey of 105 publications on east coast invertebrates in fouling communities yielded 1443 records for 317 species (see complete set of these records in
Table S2 in the supplement at www.int-res.com/ articles/suppl/m458p255_supp.pdf). An ordered ranking based on the number of records per phylum is as follows: Bryozoa (402), Cnidaria (308), Chordata (300), Arthropoda (140), Mollusca (97), Annelida (94), Porifera (87), and Entoprocta (15). A similar ranking based on the number of species recorded per phylum is: Bryozoa (95), Cnidaria (69), Chordata (47), Annelida (32), Arthropoda (25), Mollusca (24), Porifera (22), and Entoprocta (3). Clearly bryozoans, cnidarians, and chordates have been well represented in these fouling communities. In Table 1, we specifically identify a total of 51 species and 2 species complexes that were the most frequently reported in each phylum. There were 3 to 43 reports per species in this selection, but most of these species were reported in at least 10 publications. In contrast, most species in our survey were represented by only 1 (121), 2 (55), or 3 (41) records (Fig. 1).

Table 1. The most frequently reported invertebrate species in each of 8 phyla. Current name, date (yr-mm-dd) of entry or last change at the World Register of Marine Species (WORMS), the original reported name if different from current name, number of reports (No.), and east coast distribution from WORMS/OBIS/NAS are provided. Ranges are given by states and in wide $(\mathrm{W})$, intermediate $(\mathrm{I})$, and narrow $(\mathrm{N})$ categories (see Results for summary of overall patterns). Footnotes provide supplemental systematic and distributional sources. No distributional information is provided for multi-species complexes

\begin{tabular}{|c|c|c|}
\hline Species & No. & East coast distribution \\
\hline \multicolumn{3}{|l|}{ Porifera } \\
\hline Clathria prolifera (Ellis \& Solander); 2009-04-12; Microciona prolifera & 20 & Maine to Florida (W) \\
\hline Halichondria bowerbanki Burton; 2007-09-07 & 14 & Maine to Florida (W) \\
\hline Chalinula loosanoffi (Hartman); 2007-11-26; Haliclona loosanoffi & 7 & Maine to South Carolina (W) \\
\hline Mycale americana van Soest; 2007-07-19; M. cecilia, M. microsigmatosa & 7 & North Carolina to Florida (N) \\
\hline Halichondria panicea (Pallas); 2010-03-18 & 6 & Maine to Florida (W) \\
\hline \multicolumn{3}{|l|}{ Cnidaria } \\
\hline Ectopleura crocea (Agassiz); 2009-07-07; Tubularia crocea, Parypha crocea & 24 & Maine to Florida (W) \\
\hline Pennaria disticha (Goldfuss); 2004-12-21; Halocordyle disticha, P. tiarella & 20 & Maine to Florida $(\mathrm{W})^{\mathrm{n}, \mathrm{p}, \mathrm{q}}$ \\
\hline $\begin{array}{l}\text { Obelia dichotoma (Linnaeus); } 2004-12-21 ; \text { O. articulata, } \\
\quad \text { O. commissuralis, O. pyriformis }\end{array}$ & 15 & Maine to Florida (W) \\
\hline Eudendrium carneum Clarke; 2004-12-21 & 14 & Maine to Florida (W) \\
\hline Diadumene leucolena (Verrill); 2009-09-14; Sargatia leucolena & 12 & Maine to North Carolina (W) \\
\hline Halopteris tenella (Verrill); 2008-09-05; Schizotricha tenella & 11 & Maine to Florida (W) \\
\hline \multicolumn{3}{|l|}{ Annelida } \\
\hline \multicolumn{3}{|l|}{ Hydroides dianthus (Verrill); 2008-11-04; H. hexagona, } \\
\hline H. hexagonis, H. hexagonus, Serpula dianthus & 29 & Maine to Florida ${ }^{g}(\mathrm{~W})$ \\
\hline Sabellaria vulgaris Verrill; 2008-03-26 & 9 & Maine to Florida (W) \\
\hline $\begin{array}{l}\text { Parasabella microphthalma (Verrill); 2010-10-09; Demonax microphthalma, } \\
\text { Sabella microphthalma }\end{array}$ & 8 & Massachusetts $^{\mathrm{n}}$ to Florida (W) \\
\hline Branchiomma nigromaculata (Baird); 2010-10-05 & 4 & Florida $^{\mathrm{n}}(\mathrm{N})$ \\
\hline Spirorbis borealis Daudin; 2008-03-26 & 4 & Maine to New York (I) \\
\hline \multicolumn{3}{|l|}{ Arthropoda } \\
\hline Amphibalanus eburneus (Gould); 2010-10-22; Balanus eburneus & 33 & Maine to Florida $(\mathrm{W})^{\mathrm{i}, \mathrm{n}}$ \\
\hline Amphibalanus improvisus (Darwin); 2010-10-22; Balanus improvisus & 18 & Maine to Florida $(\mathrm{W})^{\mathrm{i}, \mathrm{n}}$ \\
\hline Balanus amphitrite species complex ${ }^{\mathrm{a}, \mathrm{f}-\mathrm{h}}$ & 14 & \\
\hline $\begin{array}{l}\text { Amphibalanus venustus (Darwin); 2010-10-22; Balanus amphitrite, } \\
\text { Balanus amphitrite niveus }\end{array}$ & 12 & Massachusetts to Florida (W) ${ }^{\mathrm{a}, \mathrm{h}, \mathrm{i}, \mathrm{n}}$ \\
\hline Semibalanus balanoides (Linnaeus); 2004-12-21; Balanus balanoides & 11 & Maine to New Jersey (I) \\
\hline Balanus trigonus Darwin; 2004-12-21 & 7 & North Carolina ${ }^{1}$ to Florida $(\mathrm{N})^{\mathrm{a}, \mathrm{g}}$ \\
\hline
\end{tabular}


Table 1 (continued)

\begin{tabular}{|c|c|c|}
\hline Species & No. & East coast distribution \\
\hline \multicolumn{3}{|l|}{ Mollusca } \\
\hline Mytilus edulis Linnaeus; 2004-12-21 & 22 & Maine $^{\mathrm{s}}$ to Georgia $(\mathrm{W})$ \\
\hline Crassostrea virginica (Gmelin); 2004-12-21; Ostrea virginica & 15 & Maine to Florida (W) \\
\hline Anomia simplex D'Orbigny; 2010-03-31; A. glabra & 11 & Maine to Florida (W) \\
\hline Ostrea equestris Say; 2010-07-09; Ostreola equestris & 9 & Virginia $^{\mathrm{n}}$ to Florida (I) \\
\hline $\begin{array}{l}\text { Ischadium recurvum (Rafinesque); 2005-05-20; Brachidontes recurvus, } \\
\text { Mytilus hamatus }\end{array}$ & 5 & Massachusetts to Florida (W) \\
\hline \multicolumn{3}{|l|}{ Entoprocta } \\
\hline Pedicellina cernua (Pallas); 2004-12-21 & 8 & Maine to Florida (W) \\
\hline Barentsia major Hincks; 2007-09-05 & 4 & Maine to Connecticut $(\mathrm{I})^{\circ}$ \\
\hline Barentsia laxa Kirkpatrick; 2007-09-05 & 3 & Maine to Florida $(\mathrm{W})^{\mathrm{k}}$ \\
\hline \multicolumn{3}{|l|}{ Bryozoa } \\
\hline Bugula neritina (Linnaeus); 2004-12-21 & 25 & Massachusetts to Florida $(\mathrm{W})^{\mathrm{c}, \mathrm{d}, \mathrm{e}}$ \\
\hline Bugula turrita (Desor); 2005-05-30 & 24 & Maine to Florida (W) \\
\hline Bowerbankia gracilis Leidy; 2004-12-21; Vesicularia gracilis & 22 & Maine to Florida (W) \\
\hline Cryptosula pallasiana (Moll); 2004-12-21; Lepralia pallasiana & 20 & Maine to Florida (W) \\
\hline Schizoporella errata species complex ${ }_{;}^{\mathrm{d}}$ S. unicornis & 19 & \\
\hline Bugula simplex Hincks; 2004-12-21; B. flabellata ${ }^{\mathrm{d}}$ & 15 & Maine to Florida $(\mathrm{W})^{\mathrm{j}}$ \\
\hline $\begin{array}{l}\text { Conopeum tenuissimum (Canu); 2010-03-22; C. tenuissem, C. tenuissium, } \\
\text { Electra crustulenta, Membranipora crustulenta }{ }^{\mathrm{d}}\end{array}$ & 15 & Maine to Florida (W) ${ }^{\mathrm{d}}$ \\
\hline Schizoporella variabilis (Leidy); S. errata, S. unicornis, Escharella variabilis ${ }^{\mathrm{d}}$ & 15 & Maine to North Carolina $(\mathrm{W})^{\mathrm{d}}$ \\
\hline Anguinella palmata van Beneden; 2004-12-21 & 13 & Massachusetts $^{\mathrm{d}}$ to Florida (W) \\
\hline Membranipora tenuis Desor; 2004-12-21; Acanthodesia tenuis ${ }^{\mathrm{t}}$ & 12 & Maine to Florida $(\mathrm{W})^{\mathrm{n}, \mathrm{t}}$ \\
\hline Bugula stolonifera Ryland; 2004-12-21 & 11 & New Hampshire ${ }^{\mathrm{j}}$ to Florida (W) ${ }^{\mathrm{d}}$ \\
\hline Electra pilosa (Linnaeus); 2004-12-21; Membranipora pilosa & 10 & Maine to North Carolina $(\mathrm{W})^{\mathrm{d}, \mathrm{k}}$ \\
\hline \multicolumn{3}{|l|}{ Chordata } \\
\hline Molgula manhattensis (De Kay); 2004-12-21 & 43 & Maine to Florida $(\mathrm{W})^{\mathrm{b}}$ \\
\hline Botryllus schlosseri (Pallas); 2004-12-21; B. gouldii & 41 & Maine to Florida (W) ${ }^{\mathrm{a}}$ \\
\hline Ciona intestinalis (Linnaeus); 2010-10-12; C. tenella & 19 & Maine to North Carolina $(\mathrm{W})^{\mathrm{u}}$ \\
\hline Styela plicata (Lesueur); 2004-12-21 & 19 & North Carolina to Florida (N) \\
\hline Perophora viridis Verrill; 2004-12-21 & 16 & Massachusetts to Florida (W) \\
\hline Botrylloides violaceus Oka; 2009-07-20; B. diegensis & 15 & Maine to Virginia $(\mathrm{I})^{\mathrm{a}}$ \\
\hline Diplosoma listerianum (Milne-Edwards); 2010-06-25; D. macdonaldi & 13 & Maine to Florida $(\mathrm{W})^{\mathrm{a}}$ \\
\hline Didemnum candidum Savigny; 2005-02-24; D. lutarium $^{\mathrm{m}}$ & 12 & Maine to Florida (W) \\
\hline Ascidia interrupta Heller; 2004-12-21; Phallusia hygomiana ${ }^{\mathrm{m}}$ & 10 & North Carolina to Florida (N) \\
\hline Styela canopus (Savigny); 2004-12-21; Cynthia partita, Styela partita & 10 & Maine to Florida $(\mathrm{W})^{\mathrm{a}}$ \\
\hline Styela clava (Herdman); 2009-05-02 & 10 & Maine to New York (I) ${ }^{a}$ \\
\hline \multicolumn{3}{|c|}{ 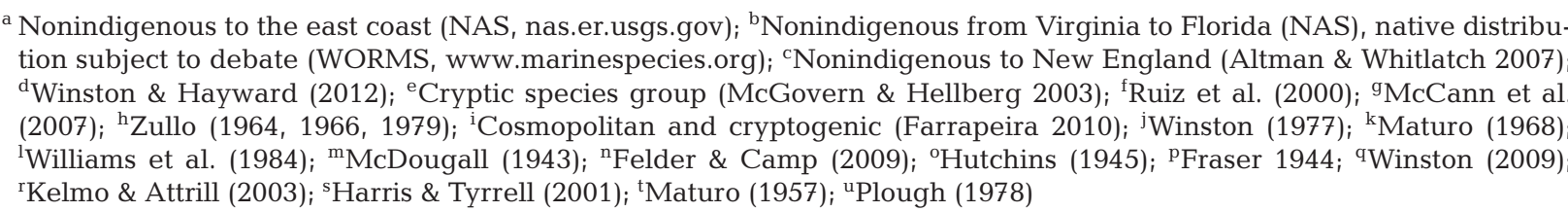 } \\
\hline
\end{tabular}

The invertebrate species in our survey range from those with very broad to those with more restricted latitudinal distributions along the east coast (see 'Methods' regarding the multiple resources used to determine these ranges). Among frequently reported species, a large majority (75\%) are widely distributed from New England to the South Atlantic Bight (designated as wide in Table 1). Among all species in our survey, there are 145 widely distributed species representing nearly half of the species total; 87 species are distributed from Maine to Florida and an additional 58 species have limits reaching as far north as Massachusetts and as far south as North Carolina. More restricted latitudinal distributions occur among 118 species, a group comprised of 22 northern species in the Gulf of Maine and/or in Massachusetts and 96 southern species occurring in the range from North Carolina to Florida (designated as narrow in Table 1). There are no reports of species in these fouling communities which are restricted to the middle range of states from Rhode Island to Virginia. On the other hand, 21 southern species and 


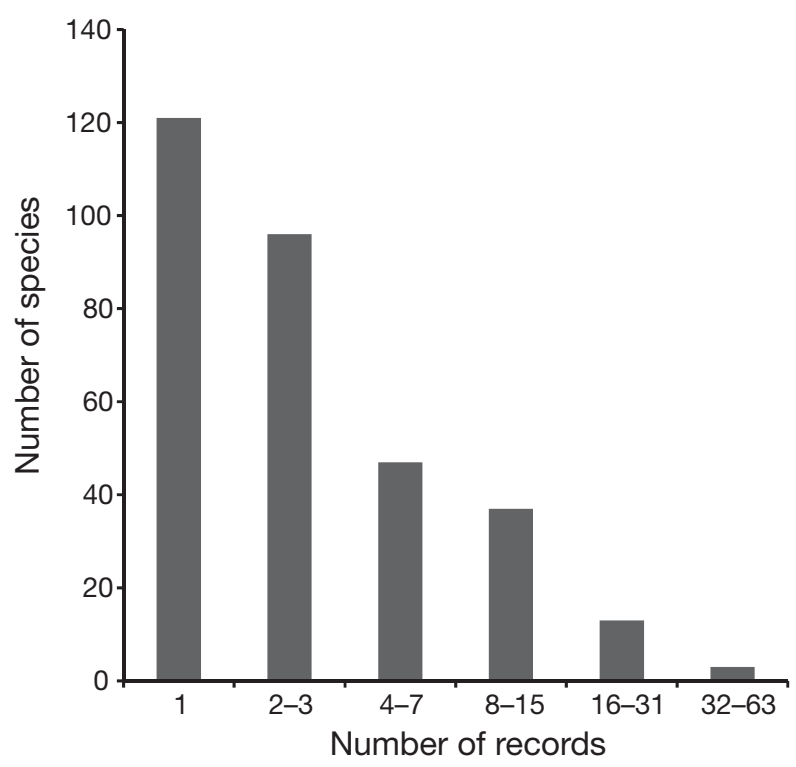

Fig. 1. Distribution of species across frequency classes representing the number of records

33 northern species extend partially into this midAtlantic region (designated as intermediate in Table 1). The most frequently reported among these species are Botrylloides violaceus, Ostrea equestris, Semibalanus balanoides, Spirorbis borealis, and Styela clava.

Assuming that each species can occur in each state between its northern and southern limits along the east coast, the number of species per state ranges between 161 species in Maine and New Hampshire and 228 species in Florida (Fig. 2). The proportion of widely distributed species in each state varies between $50 \%$ in Florida and $88 \%$ in Maryland and Delaware. Narrowly distributed species, restricted to the warmer waters south of Virginia, reach a maximum proportion of $42 \%$ in Florida. Although many of these southern species also occur elsewhere in tropical and subtropical seas, 41 species occur only in Florida along the east coast.

North of Florida, the total number of species peaks again in North Carolina and Massachusetts (Fig. 2). These peaks occur with changes in the distributions of both widely and narrowly distributed species. The number of widely distributed species remains the same from Massachusetts to North Carolina, but drops by $21 \%$ north of Massachusetts and by $22 \%$ south of North Carolina. In Massachusetts, 145 widely distributed species co-occur with 21 northern, narrowly distributed species and 33 additional northern species with ranges extending into Long Island Sound or along the mid-Atlantic Bight. In North Car-

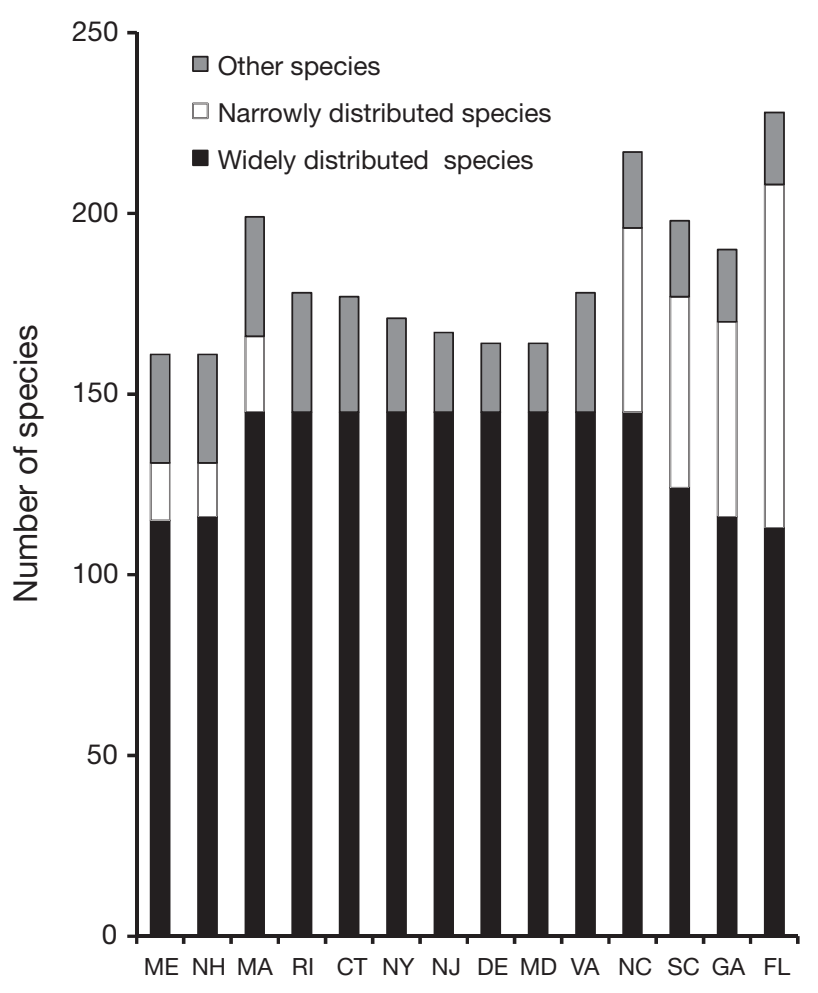

Fig. 2. Number of species in the fouling communities of each state along the east coast. Each species is assumed to occur in all states between the northern and southern limits. Widely distributed species occur at least as far north as Massachusetts and as far south as North Carolina. Narrowly distributed species are restricted from Maine to Massachusetts or from North Carolina to Florida. Other species with intermediate distributions are also indicated. ME: Maine; NH: New Hempshire; MA: Massachusetts; RI: Rhode Island; CT: Connecticut; NY: New York; NJ: New Jersey; DE: Delaware; MD: Maryland; VA: Virginia; NC: North Carolina; SC: South Carolina; GA: Georgia; FL: Florida

olina, 51 southern, narrowly distributed species reach their northern limit, occurring along with 145 widely distributed species.

Among the 317 fouling community species in our study, 29 species have been reported to be nonindigenous to the east coast (McCann et al. 2007, Nonindigenous Aquatic Species [NAS], nas.er.usgs. gov). Among the frequently reported species identified in Table 1, those designated as nonindigenous include barnacles (Amphibalanus venustus, Balanus trigonus, and the Balanus amphitrite species complex for reports where we could not attribute them to currently recognized species), 1 bryozoan (Bugula neritina), and several ascidians (Botrylloides violaceus, Botryllus schlosseri, Diplosoma listerianum, Molgula manhattensis, Styela canopus, and S. clava). Among the less frequently reported species, there 
are 4 cnidarian, 1 annelid, 3 barnacle, 2 molluscan, 7 bryozoan, and 3 ascidian species (Table 2). Among all 29 species, 12 are widely distributed (as defined above) and 7 are narrowly distributed southern species occurring only in the South Atlantic Bight.

In the community-level analyses, there was consistent latitudinal variation among studies, regardless of whether the data were analyzed as a whole or by time period (Early, Mid, or Recent) or species group (native or invasive). For all studies including 3 or more phyla, the MDS plot depicts a clearly evident trend of increasing dissimilarity from Florida to northern New England (Fig. 3). Similarly, the MDS plot for Recent studies illustrates this general latitudinal trend (Fig. 4C). There were fewer studies in the Early and Mid time periods, but some degree of regional clumping and latitudinal variation is evident in the MDS plots (Fig. 4A,B). Finally, separate evaluation of native and invasive species revealed latitudinal variation, especially between the northern fauna in New England and the southern fauna in South Carolina, Georgia, and Florida (Fig. 5). Significant differences in faunal composition were evident among regional groupings for native species (ANOSIM Global R = 0.436, $\mathrm{p}=0.001$, Fig. 5A) and for invasive species (ANOSIM Global R = 0.554, $\mathrm{p}=0.001$, Fig. 5B).

\section{DISCUSSION}

The most frequently reported species in our survey were 2 ascidians, Botryllus schlosseri and Molgula

Table 2. Less frequently reported, nonindigenous invertebrate species in east coast fouling communities. Current name, date (yr-mm-dd) of entry or last change at the World Register of Marine Species (WORMS), the original reported name if different from current name, number of reports (No.), and east coast distribution from WORMS/OBIS/NAS are provided. Ranges are given by states and in wide (W), intermediate (I), and narrow (N) categories. Footnotes provide supplemental systematic and distributional sources

\begin{tabular}{|c|c|c|}
\hline Species & No. & East coast distribution \\
\hline \multicolumn{3}{|l|}{ Cnidaria } \\
\hline $\begin{array}{l}\text { Diadumene lineata (Verrill); 2009-12-22; Aiptasiamorpha luciae, } \\
\text { Haliplanella luciae }\end{array}$ & 7 & Massachusetts to Florida $(\mathrm{W})^{\mathrm{a}}$ \\
\hline Cordylophora caspia (Pallas); 2004-12-21 & 2 & Maine to Florida $(\mathrm{W})^{\mathrm{a}}$ \\
\hline Garveia franciscana (Torrey); 2004-12-21 & 2 & Maine to Florida $(\mathrm{W})^{\mathrm{a}, \mathrm{c}}$ \\
\hline Moerisia lyonsi Boulenger; 2004-12-21 & 2 & Delaware to South Carolina $(\mathrm{I})^{\mathrm{a}, \mathrm{i}-\mathrm{l}}$ \\
\hline \multicolumn{3}{|l|}{ Annelida } \\
\hline Ficopomatus enigmaticus (Fauvel); 2008-11-04 & 1 & Virginia to Florida $(\mathrm{I})^{\mathrm{a}, \mathrm{b}}$ \\
\hline \multicolumn{3}{|l|}{ Arthropoda } \\
\hline $\begin{array}{l}\text { Megabalanus tintinnabulum (Linnaeus); 2004-12-21; Balanus tintinnabulum, } \\
\text { M. antillensis }{ }^{\mathrm{g}}\end{array}$ & 7 & Massachusetts to Florida $(\mathrm{W})^{\mathrm{a}}$ \\
\hline Amphibalanus amphitrite (Darwin); 2009-10-06; Balanus amphitrite & 1 & Massachusetts to Florida (W) ${ }^{\mathrm{a}, \mathrm{e}, \mathrm{f}}$ \\
\hline Amphibalanus reticulatus (Utinomi); 2009-10-06; Balanus reticulatus & 1 & Florida $(\mathrm{N})^{\mathrm{a}, \mathrm{d}}$ \\
\hline \multicolumn{3}{|l|}{ Mollusca } \\
\hline Mytilopsis leucophaeata (Conrad); 2005-05-20; Congeria leucopheata & 2 & New York to Florida $(\mathrm{I})^{\mathrm{a}, \mathrm{c}}$ \\
\hline Perna viridis (Linnaeus); 2008-10-01 & 1 & South Carolina to Florida $(\mathrm{N})^{\mathrm{a}}$ \\
\hline \multicolumn{3}{|l|}{ Bryozoa } \\
\hline Membranipora membranacea (Linnaeus); 2004-12-21 & 6 & Maine to Florida $(\mathrm{W})^{\mathrm{a}}$ \\
\hline Victorella pavida Saville Kent; 2004-12-21 & 4 & New York ${ }^{\mathrm{h}}$ to Florida $(\mathrm{I})^{\mathrm{a}}$ \\
\hline Celleporaria pilaefera (Canu \& Bassler); 1997-12-03 & 1 & Florida $(\mathrm{N})^{\mathrm{d}}$ \\
\hline Electra bengalensis (Stoliczka); 2010-04-27 & 1 & Florida $(\mathrm{N})^{\mathrm{d}}$ \\
\hline Hippoporina indica Madhavan Pillai; 2010-04-27 & 1 & Virginia to Florida $(\mathrm{I})^{\mathrm{d}}$ \\
\hline Sinoflustra annae (Osburn); 2009-05-18 & 1 & Florida $(\mathrm{N})^{\mathrm{d}}$ \\
\hline Sundanella sibogae (Harmer); 2009-05-18 & 1 & North Carolina to Florida $(\mathrm{N})^{\mathrm{a}, \mathrm{c}, \mathrm{d}}$ \\
\hline \multicolumn{3}{|l|}{ Chordata } \\
\hline Ascidiella aspersa (Müller); 2004-12-21 & 8 & Maine to North Carolina $(\mathrm{W})^{\mathrm{a}}$ \\
\hline Ecteinascidia turbinata Herdman; 2004-12-21 & 3 & Virginia to Florida $(\mathrm{I})^{\mathrm{a}, \mathrm{b}}$ \\
\hline Didemnum vexillum Kott; 2009-11-28; D. vestum & 2 & Maine to New York $(\mathrm{I})^{\mathrm{a}}$ \\
\hline \multicolumn{3}{|c|}{ 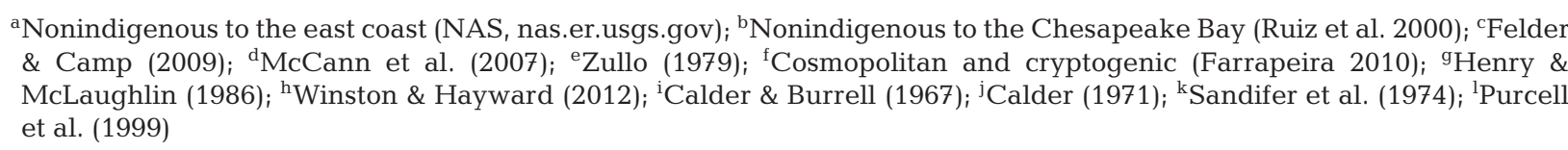 } \\
\hline
\end{tabular}


- Northern New England $\quad$ Southern Mid-Atlantic $\quad$ Florida

$\checkmark$ Southern New England $\quad$ North Carolina

$\Delta$ Northern Mid-Atlantic o South Atlantic Bight

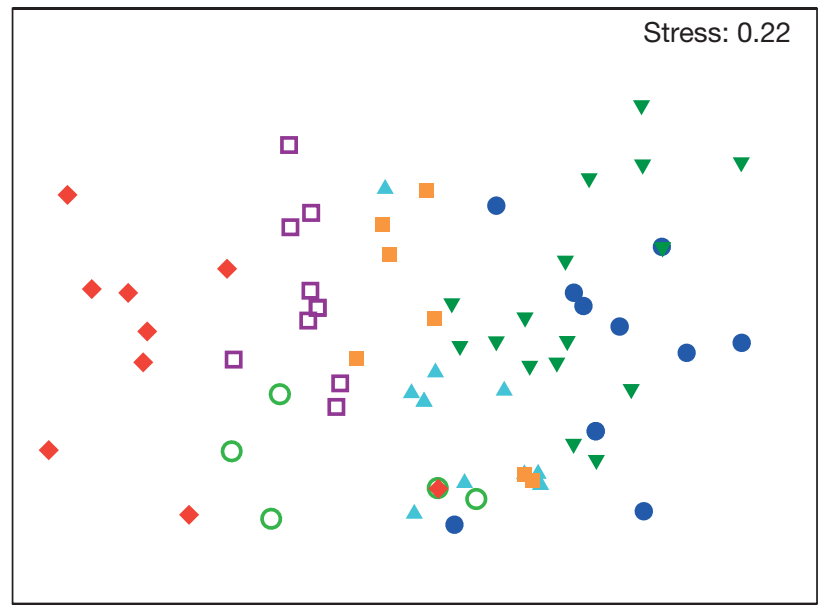

Fig. 3. MDS plot of Bray-Curtis dissimilarities in species composition among sites. All studies include 3 or more phyla. Each point represents a single study or each state for studies reporting on multiple states. Sites are designated within 7 regions along the east coast (see 'Methods' for more detail)

manhattensis, with 41 and 43 reports, respectively (Table 1), dating back to early studies in Massachusetts (Verrill \& Smith 1874). Ascidians such as these are widespread and well known for their ability to numerically dominate fouling communities in different geographic regions (e.g. Scheer 1945, Sutherland \& Karlson 1977, Dijkstra et al. 2007a,b). Both species are also invasive along some or all of the east coast (Table 1). Twenty-nine invasive species represented $9.1 \%$ of all species in the survey and between $6.8 \%$ (Maine and New Hampshire) and $10.7 \%$ (Virginia) of the species estimated for each state. The Chordata, as
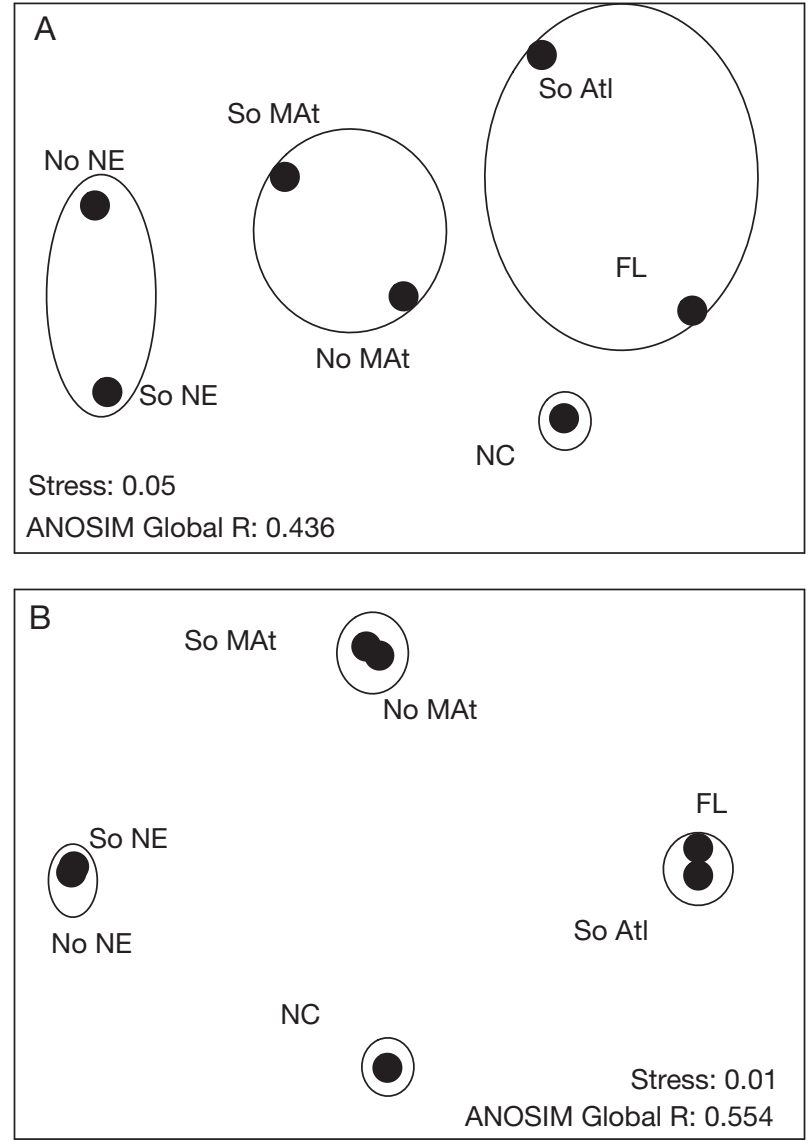

Fig. 5. MDS plots of Bray-Curtis dissimilarities among the 7 regions for species classified as (A) native or (B) invasive. The ellipses link regions with greater than $70 \%$ similarity. Note the latitudinal variation among regions (see 'Methods' for more detail). Regions: Northern New England (No NE), Southern New England (So NE), Northern Mid-Atlantic (No MAt), Southern Mid-Atlantic (So MAt), North Carolina (NC), South Atlantic Bight (So Atl) and Florida (FL)

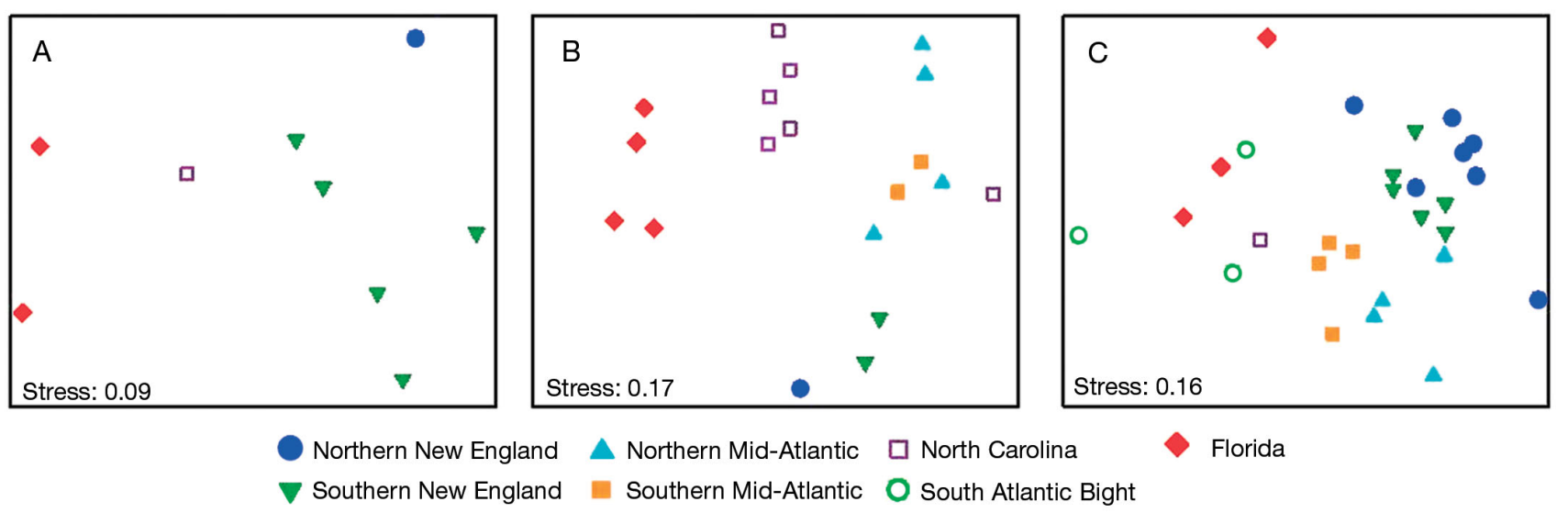

Fig. 4. MDS plots of studies classified by period of publication. Periods are (A) Early (1948 or earlier), (B) Mid (1949 to 1982), and (C) Recent (1983 to 2009). Methods as in Fig. 3 
represented by ascidians in these fouling records, were the third most frequently reported phylum in terms of numbers of records. The Bryozoa and Cnidaria were the most frequently reported phyla, representing $49 \%$ of all reports and $52 \%$ of all species.

One striking feature of these frequency data is the large number of species reported in the literature only 1 to 3 times (here designated as rare species). These species represent $68 \%$ of the 317 species (Fig. 1). This probably indicates undersampling of the regional pool of species suggesting that additional sampling effort and more comprehensive surveys would add many additional species to those comprising fouling communities. Typically, many ecological studies use analytical methods requiring one to focus on the most abundant species, so very rare species are often not reported (e.g. Sutherland \& Karlson 1977, Karlson 1978). Nevertheless, rare species are a common component of most fouling community studies. Here they represent $70 \%$ of 253 species reported in 55 community studies. Although it is possible that misidentifications have erroneously inflated the proportion of rare species in this literature survey, it is unlikely that most of these species were misidentified.

The distribution of species can be viewed on multiple spatial scales representing, for example, several localities, states, regions, and entire coastlines. Above, we have summarized distributional patterns by noting that most frequently reported species are widely distributed, occurring from New England to the South Atlantic Bight, and many of these range all the way from Maine to Florida. This pattern indicates that Cape Cod and Cape Hatteras do not represent distributional boundaries for many species $(46 \%$ of the fauna in this case). An additional group of 33 northern species and 21 southern species extend beyond one of these capes reaching a distributional limit in the midAtlantic region. Thus, $63 \%$ of the fauna have distributional ranges extending beyond these putative boundaries.

On the other hand, this fouling community fauna does include species which are not known to extend south of Cape Cod or north of Cape Hatteras. Twenty-two northern species range to the south only as far as Massachusetts, while 96 southern species occur only from North Carolina to Florida. The Bryozoa and Chordata are well represented among the reported species in these 2 regions (61\%). Recent systematic revisions of the Bryozoa north of Cape Hatteras confirm that the boreal region north of Cape Cod is more diverse than that occurring in the temperate water between the capes (Winston \& Hayward
2012). We found 7 bryozoan species constituting $32 \%$ of the fouling community species restricted to these boreal waters. Across the entire east coast, 30\% of the species in this community are bryozoans.

There are 2 major distributional patterns exhibited by species restricted to the South Atlantic Bight. Fifty species occur over the full range from North Carolina to Florida, while 41 are known only for Florida. The former group is comprised of warm-water species occurring no farther north than Hatteras Harbor (Wells et al. 1964) or the offshore hard-bottom of Onslow Bay (Williams et al. 1984). Several tropical species, including the corals Siderastrea siderea (Ellis \& Solander) and Solenastrea hyades (Dana) (see Macintyre \& Pilkey 1969), other sessile taxa, the echinoid Diadema antillarum, and multiple fish species, are also known to occur in Onlsow Bay (M. Hooper pers. comm.). For these species, the distributional break at Cape Hatteras is consistent with the oceanographic conditions emphasized by Longhurst (2007). The latter group in Florida is dominated by 19 bryozoan species. Some of these species are new to Florida waters as a result of species invasions (Table 2, see McCann et al. 2007) and, possibly, range extensions from tropical waters (Winston 2009). Further northward movement in the future, at least to Cape Hatteras, would appear to be likely.

In our analysis of community-level studies, we found additional support for regional differences in fouling communities (Figs. 3, 4 \& 5). In large part, the regions separate into New England, Mid-Atlantic, North Carolina, and South Carolina to Florida. Such latitudinal variation is evident here and in other recent analyses of benthic invertebrates along the east coast (Engle \& Summers 1999, Cook \& Auster 2007, Hale 2010). These patterns appear not to change with more recent species invasions. Even though the distribution of more southern species such as Ecteinascidia turbinata and Symplegma viride have shifted northward, many of the species that have invaded northern regions (e.g. Botrylloides violaceus, Styela clava, Didemnum vexillum) in the past $40 \mathrm{yr}$ are not found in southern regions. Yet, these same southern regions have been invaded by different species during the same time period (e.g. Celleporaria pilaefera, Electra bengalensis, Sinoflustra annae).

Thus the fouling community along the east coast of the USA is a composite assembly of mostly widespread species tolerant of a wide range of water temperatures, cold-water boreal species, and tropical species with varying degrees of cold-tolerance. This view is mostly consistent with Gosner (1971), with his 
references to the transitional nature of the invertebrate fauna along the east coast and the strong contribution made by tropical species to the fauna of the American Atlantic Temperate Region. Currently, many boreal and tropical species appear to be limited by either Cape Cod or Cape Hatteras, but oceanographic conditions (mean flows and variability associated with the NAO, prevailing winds, storms, etc.) can facilitate range extensions around these physical obstructions (see Introduction). Given that oceanographers have begun to consider the dynamics of variable flow (as opposed to focusing primarily on mean flows) in coastal waters (see Introduction), we should anticipate learning more in the future about how distributional limits of fouling and non-fouling species are dictated by physical processes. In addition, physiological studies on the influence of temperature on reproduction, growth, and mortality (e.g. Jones et al. 2009) will be useful, especially as the seas continue to warm. The future is likely to include more species invasions and northward extensions of warm-water species along much of the east coast.

In fact, one of us (R. W. Osman) has examined unpublished evidence from ongoing recruitment and other experimental studies in New England (Long Island Sound), the mid-Atlantic (Chesapeake Bay and a Virginia coastal bay), and Florida (Indian River Lagoon). As we have found in the literature, there are species that are common and abundant in all of these regions (e.g. Amphibalanus improvisus and Molgula manhattensis) but others that are present and abundant in only 1 region (e.g. Styela clava in Long Island Sound, Membranipora chesapeakensis in Chesapeake Bay, and Megabalanus cocopoma in Indian River Lagoon). In addition, many of the invasive species seen in Long Island Sound are not found in the Indian River Lagoon (e.g. Botrylloides violaceus, Styela clava, Didemnum vexillum, Membranipora membranacea, and Clavelina lepadiformis; see Reinhardt et al. 2010), although other species of these same genera are. The maintenance of similar regional patterns over time (Fig. 4) and with both resident and invasive species (Fig. 5) suggests that even with an increasing potential of northern movement of southern species, latitudinal differences in environmental conditions continue to influence distributional patterns. These patterns remain despite the likely human assistance, both in terms of increased and faster shipping (hull fouling and ballast water) and increasing man-made structures along the coast, but, most importantly, in areas with little natural habitat.
In conclusion, we note that the currently accepted nomenclature differed from earlier usage by the authors in our survey for 127 of the 317 species. Most of these differences are due to systematic revisions by taxonomic specialists, but a few misidentifications and misspellings are also in the record. We attempted to correct these latter 2 cases where possible. The largest number of differences were among the Bryozoa (41 of 95 species) and the largest proportion of differences among the Porifera (55\% of 22 species). Some notable recent changes among the frequently reported species include the sponge Clathria prolifera, previously Microciona prolifera, the hydroids Ectopleura crocea, previously Tubularia crocea, and Obelia dichotoma, and multiple barnacle species Amphibalanus spp. (Tables 1 \& 2). Such a large number of changes behooves ecologists to follow the systematic literature closer than has been the case in the past. This is especially true as molecular evidence supports species distinctions among morphologically similar forms. For example, McGovern \& Hellberg (2003) reported 2 cryptic species occurring north and south of Cape Hatteras within what we call Bugula neritina (Winston \& Hayward 2012). As cryptic speciation is predicted to be widespread among colonial invertebrates (Hughes 2005), we should expect more such examples of cryptic species in the future.

In the course of undergoing this survey, it became apparent that some taxa still require more attention. As examples, we note 2 species common in North Carolina which play a key ecological role in the dynamics of fouling communities in the presence of intense grazing by the echinoid Arbacia punctulata. One is the conspicuous bright orange sponge Xestospongia halichondrioides (misspelled as $X$. halichondroides in Karlson 1978). This sponge is known to occur from the Gulf of Mexico to North Carolina (Wells 1969, Ruppert \& Fox 1988). However, Xestospongia halichondrioides is not a valid name and the spicules from museum specimens do not match the putative holotype slide for Petrosia halichondrioides as suggested by Wells et al. (1960) (see Acknowledgements). On the other hand, the spicules are similar to those of Pseudospongosorites suberitoides. It is recommended that fresh material from the southeastern USA be analyzed to resolve this systematic problem.

The second species in need of attention is Hydractinia sp., an encrusting hydroid common in the fouling communities of Virginia and North Carolina (McDougall 1943, Calder \& Brehmer 1967, Calder 1971, Sutherland \& Karlson 1977, Karlson 1978). All of these studies reported this hydroid to be Hydrac- 
tinia echinata. Based on molecular evidence from specimens collected on shells occupied by hermit crabs, Buss \& Yund (1989) identified H. symbiolongicarpus, $H$. symbiopollicaris, and $H$. polyclina as part of a sibling species complex of western Atlantic Hydractinia that 'are distinct from $H$. echinata'. Cairns et al. (2002) stated that this group of species still needs more molecular analysis to resolve taxonomic problems. Some continue to recognize $H$. echinata in the eastern Atlantic and the Gulf of Mexico (Felder \& Camp 2009). Others indicate H. echinata occurs in the northwestern Atlantic, but only as far south as Long Island Sound (C. Cunningham pers. comm.). Based on extensive molecular evidence, Miglietta et al. (2009) confirm 'deep divergence' between the Hydractinia in the Gulf of Mexico and in the Northwest Atlantic. Yet the debate over species designations in Europe, the Gulf of Mexico, and the Northwest Atlantic still leaves our reports from Virginia and North Carolina fouling communities in question. Given the likelihood of future changes in distributions, the taxonomic status of this temperate warm-water species needs resolution.

Acknowledgements. We thank B. Kirby-Smith, Director of the Natural History Resource Center at the Duke University Marine Laboratory, for his assistance in getting a sample (DUML 2765) of Xestospongia halichondrioides (Wilson) re-examined by K. Ruetzler at the National Museum of Natural History, Washington (formerly US National Museum; USNM). K. Ruetzler was very generous in taking the time to examine this sample and compare it with another North Carolina sample (USNM 23622; see Wells et al. 1960, Wells 1969), a Florida sample of Spongosorites suberitoides Diaz, Pomponi, and van Soest (USNM 32441; Diaz et al. 1993) (now accepted as Pseudospongosorites suberitoides; see McCormack \& Kelly 2002), and the holotype slide of Petrosia halichondrioides Wilson from St. Thomas, US Virgin Islands (USNM 7663; see Wilson 1902) (now Plakortis halichondrioides). K. Ruetzler and R. van Soest conferred about these samples and made recommendations for further analysis (see Discussion). We thank D. Calder (hydroids), L. Buss and C. Cunningham (hydractiniids), R. van Soest (sponges), and J. Winston (bryozoans) for their guidance on other nomenclature revisions and we thank M. Hooper for sharing his experience with the epibenthic fauna of Onslow Bay.

\section{LITERATURE CITED}

Altman S, Whitlatch RB (2007) Effects of small-scale disturbance on invasion success in marine communities. J Exp Mar Biol Ecol 342:15-29

Boicourt WC, Wiseman WJ Jr., Valle-Levinson A, Atkinson LP (1998) Continental shelf of the southeastern United States and the Gulf of Mexico: in the shadow of the western boundary current. In: Robinson AR, Brink KH (eds) The sea. Vol 11. Ideas and observations in the study of the sea. John Wiley \& Sons, New York, NY, p 135-182
Bulleri F, Chapman MG (2010) The introduction of coastal infrastructure as a driver of change in marine environments. J Appl Ecol 47:26-35

Buss LW, Yund PO (1989) A sibling species group of Hydractinia in the northeastern United States. J Mar Biol Assoc UK 69:857-874

Cairns SD, Calder DR, Brinckmann-Voss A, Castro CB and others (2002) Common and scientific names of aquatic invertebrates from the United States and Canada: Cnidaria and Ctenophora. Spec Publ Am Fish Soc 28

Calder DR (1971) Hydroids and hydromedusae of southern Chesapeake Bay. Va Inst Mar Sci Spec Pap Mar Sci 1: $1-125$

Calder DR, Brehmer ML (1967) Seasonal occurrence of epifauna on test panels in Hampton Roads, Virginia. Int J Oceanol Limnol 1:149-164

Calder DR, Burrell VG Jr (1967) Occurrence of Moerisia lyonsi (Limnomedusae, Moerisiidae) in North America. Am Midl Nat 78:540-541

Cerame-Vivas MJ, Gray IE (1966) The distributional pattern of benthic invertebrates of the continental shelf off North Carolina. Ecology 47:260-270

$>$ Coles WC, Musick JA (2000) Satellite sea surface temperature analysis and correlation with sea turtle distribution in North Carolina. Copeia 2000:551-554

Cook RR, Auster PJ (2007) A bioregional classification for the continental shelf of northeastern North America for conservation analysis and planning based on representation. US Department of Commerce, NOAA, Mar Sanc Cons Ser NMSP-07-03

Cornell HV, Lawton JH (1992) Species interactions, local and regional processes, and limits to the richness of ecological communities: a theoretical perspective. J Anim Ecol 61:1-12

de Laubenfels MW (1949) The sponges of Woods Hole and adjacent waters. Bull Mus Comp Zool Harvard Univ 103: $1-55$

Diaz MC, Pomponi SA, van Soest RWM (1993) A systematic revision of the central West Atlantic Halichondrida (Demospongiae, Porifera). Part III. Description of valid species. Sci Mar 57:283-306

> Dijkstra J, Harris LG, Westerman E (2007a) Distribution and long-term temporal patterns of four invasive colonial ascidians in the Gulf of Maine. J Exp Mar Biol Ecol 342: $61-68$

> Dijkstra J, Sherman H, Harris LG (2007b) The role of colonial ascidians in altering biodiversity in marine fouling communities. J Exp Mar Biol Ecol 342:169-171

Engle VD, Summers JK (1999) Latitudinal gradients in benthic community composition in Western Atlantic estuaries. J Biogeogr 26:1007-1023

> Farrapeira CMR (2010) Shallow water Cirripedia of the northeastern coast of Brazil: the impact of life history and invasion on biogeography. J Exp Mar Biol Ecol 392:210-219

Felder DL, Camp DK (eds) (2009) Gulf of Mexico origin, waters, and biota, Vol 1, Biology. Texas A\&M University Press, College Station, TX

Fraser CMcL (1944) Hydroids of the Atlantic coast of North America. University of Toronto Press, Toronto

Gosner KL (1971) Guide to identification of marine and estuarine invertebrates. Cape Hatteras to the Bay of Fundy. John Wiley \& Sons, New York, NY

> Hale SS (2010) Biogeographical patterns of marine benthic macroinvertebrates along the Atlantic coast of the northeastern USA. Estuaries Coasts 33:1039-1053 
Hargitt CW (1908) Notes on a few Coelenterates from Woods Holl. Biol Bull 14:95-120 (Woods Hole)

- Harris LG, Tyrrell MC (2001) Changing community states in the Gulf of Maine: synergism between invaders, overfishing, and climate change. Biol Invasions 3:9-21

Henry DP, McLaughlin PA (1986) The recent species of Megabalanus (Cirripedia: Balanomorpha) with special emphasis on Balanus tintinnabulum (Linnaeus) sensu lato. Zool Verh 235:3-60

> Hogg NG (1992) On the transport of the Gulf Stream between Cape Hatteras and the Grand Banks. Deep-Sea Res A 39:1231-1246

> Hughes RN (2005) Lessons in modularity: the evolutionary ecology of colonial invertebrates. Sci Mar 69(Suppl 1): 169-179

Hutchins LW (1945) An annotated checklist of the salt-water bryozoa of Long Island Sound. Trans Conn Acad Arts Sci 36:533-551

> Jones SJ, Mieszkowska N, Wethey DS (2009) Linking thermal tolerances and biogeography: Mytilus edulis (L.) at its southern limit on the east coast of the United States. Biol Bull 217:73-85 (Woods Hole)

- Karlson R (1978) Predation and space utilization patterns in a marine epifaunal community. J Exp Mar Biol Ecol 31: 225-239

Kelmo F, Attrill MJ (2003) Shallow-water Campanulariidae (Hydrozoa, Leptothecatae) from northern Bahia, Brazil. Rev Biol Trop 51:123-146

Kritzer JP, Sale PF (eds) (2006) Marine metapopulations. Elsevier Academic Press, San Diego, CA

Loder JW, Petrie B, Gawarkiewicz G (1998) The coastal ocean off northeastern North America: a large-scale view. In: Robinson AR, Brink KH (eds) The sea, Vol 11. Ideas and observations in the study of the sea. John Wiley \& Sons, New York, NY, p 105-133

Longhurst AR (2007) Ecological geography of the sea. Academic Press, Boston, MA

Macintyre IG, Pilkey OH (1969) Tropical reef corals: tolerance of low temperatures on the North Carolina continental shelf. Science 166:374-375

Martinez AJ (2010) Marine life of the North Atlantic: Canada to Cape May. Aqua Quest Publications, Locust Valley, NY

Maturo FJS Jr. (1957) A study of the bryozoa of Beaufort, North Carolina, and vicinity. J Elisha Mitchell Sci Soc 73: 11-68

Maturo FJS Jr. (1968) The distributional pattern of the Bryozoa of the east coast of the United States exclusive of New England. Atti Soc Ital Sci Nat 108:261-284

Maturo FJS Jr., Schopf TJM (1968) Ectoproct and Entoproct type material: reexamination of species from New England and Bermuda named by A.E. Verrill, J.W. Dawson, and E. Desor. Postilla 120:1-95

McCann LD, Hitchcock NG, Winston JE, Ruiz GM (2007) Non-native bryozoans in coastal embayments of the southern United States: new records for the western Atlantic. Bull Mar Sci 80:319-342

> McCormack GP, Kelly M (2002) New indications of the phylogenetic affinities of Spongosorites suberitoides Diaz et al. 1993 (Porifera, Demospongiae) as revealed by 28S ribosomal DNA. J Nat Hist 36:1009-1021

McDougall KD (1943) Sessile marine invertebrates of Beaufort, North Carolina. A study of settlement, growth, and seasonal fluctuations among pile-dwelling organisms. Ecol Monogr 13:321-374
McGovern TM, Hellberg ME (2003) Cryptic species, cryptic endosymbionts, and geographic variation in chemical defences in the bryozoan Bugula neritina. Mol Ecol 12: 1207-1215

> Miglietta MP, Schuchert P, Cunningham CW (2009) Reconciling genealogical and morphological species in a worldwide study of the Family Hydractiniidae (Cnidara, Hydrozoa). Zool Scr 38:403-430

> Mora C, Tittensor DP, Adl S, Simpson AGB, Worm B (2011) How many species are there on earth and in the ocean? PLoS Biol 9:e1001127

> Nixon SW, Granger S, Buckley BA, Lamont M, Rowell B (2004) A one hundred and seventeen year coastal water temperature record for Woods Hole, Massachusetts. Estuaries 27:397-404

Nutting CC (1901) The hydroids of the Woods Hole region. US Fish Comm Bull 19:325-386

Osburn RC (1910) The bryozoa of the Woods Hole region. Bull US Bur Fish 30:203-266

Osman RW (1977) The establishment and development of a marine epifaunal community. Ecol Monogr 47:37-63

Osman RW (1978) The influence of seasonality and stability on the species equilibrium. Ecology 59:383-399

Plough HH (1978) Sea squirts of the Atlantic continental shelf from Maine to Texas. Johns Hopkins University Press, Baltimore, MD

Pollock LW (1998) A practical guide to the marine animals of northeastern North America. Rutgers University Press, New Brunswick, NJ

> Purcell JE, Båmstedt U, Båmstedt A (1999) Prey, feeding rates, and asexual reproduction rates of the introduced oligohaline hydrozoan Moerisia lyonsi. Mar Biol 134: 317-325

Reinhardt JF, Stefaniak LM, Hudson DM, Mangiafico J, Gladych R, Whitlatch RB (2010) First record of the nonnative light bulb tunicate Clavelina lepadiformis (Müller, 1776) in the northwest Atlantic. Aquat Invas 5:185-190

Richardson PL, Knauss JA (1971) Gulf Stream and western boundary undercurrent observations at Cape Hatteras. Deep-Sea Res A 18:1089-1109

Ricklefs RE, Schluter D (eds) (1993) Species diversity in ecological communities: historical and geographical perspectives. The University of Chicago Press, Chicago, IL

Roughgarden J (2006) Foreword. In: Kritzer JP, Sale PF (eds) Marine metapopulations. Elsevier Academic Press, San Diego, CA, p xvii-xx

Ruiz GM, Fofonoff P, Hines AH (1999) Non-indigenous species as stressors in estuarine and marine communities: Assessing invasion impacts and interactions. Limnol Oceanogr 44:950-972

Ruiz GM, Fofonoff PW, Carlton JT, Wonham MJ, Hines AH (2000) Invasion of coastal marine communities in North America: apparent patterns, processes, and biases. Annu Rev Ecol Syst 31:481-531

Ruppert EE, Fox RS (1988) Seashore animals of the southeast: a guide to common shallow-water invertebrates of the southeastern Atlantic coast. University of South Carolina Press, Columbia, SC

Sandifer PA, Smith TIJ, Calder DR (1974) Hydrozoans as pests in closed-system culture of larval decapod crustaceans. Aquaculture 4:55-59

Scheer BT (1945) The development of marine fouling communities. Biol Bull 89:103-121 (Woods Hole)

Smith RI (ed) (1964) Keys to marine invertebrates of the Woods Hole region. Contribution No. 11, Systematics- 
Ecology Program, Marine Biological Laboratory, Woods Hole, MA

Sorte CJB, Stachowicz JJ (2011) Patterns and processes of compositional change in a California epibenthic community. Mar Ecol Prog Ser 435:63-74

Sorte CJB, Williams SL, Zerebecki RA (2010) Ocean warming increases threat of invasive species in a marine fouling community. Ecology 91:2198-2204

Soto IM, Muller Karger FE, Hallack P, Hu C (2011) Sea surface temperature variability in the Florida Keys and its relationship to coral cover. J Mar Biol, Article ID: 981723 doi: 10.1155/2011/981723

Stachowicz JJ, Terwin JR, Whitlatch RB, Osman RW (2002) Linking climate change and biological invasions: ocean warming facilitates nonindigenous species invasions. Proc Natl Acad Sci USA 99:15497-15500

Sumner FB, Osburn RC, Cole LJ (1911) A biological survey of the waters of Woods Hole and vicinity. Part I. Bull US Bur Fish 31:5-442

Sumner FB, Osburn RC, Cole LJ (1913) A biological survey of the waters of Woods Hole and vicinity. Part II. Bull US Bur Fish 31:549-794

Sutherland JP, Karlson RH (1977) Development and stability of the fouling community at Beaufort, North Carolina. Ecol Monogr 47:425-446

Van Name WG (1945) The North and South American ascidians. Bull Am Mus Nat Hist 84:1-476

Verrill AE, Smith SI (1874) Report upon the invertebrate animals of Vineyard Sound and adjacent waters, with an account of the physical features of the region. Washington, DC

Weiss HM (1995) Marine animals of southern New England and New York: Identification keys to common nearshore and shallow water macrofauna. State Geological and Natural History Survey of Connecticut, Department of Environmental Protection, Bulletin 115, Hartford, CT

Wells HW (1969) Hydroid and sponge commensals of Cantharus cancellarius with a 'false shell'. Nautilus 82: 93-102

- Wells HW, Gray IE (1960) The seasonal occurrence of

Editorial responsibility: Pei-Yuan Qian,

Kowloon, Hong Kong SAR
Mytilus edulis on the Carolina coast as a result of transport around Cape Hatteras. Biol Bull (Woods Hole) 119: 550-559

Wells HW, Wells MJ, Gray IE (1960) Marine sponges of North Carolina. J Elisha Mitchell Sci Soc 76:200-245

Wells HW, Wells MJ, Gray IE (1964) Ecology of sponges in Hatteras Harbor, North Carolina. Ecology 45:752-767

Williams AH, Sutherland JP, Hooper MR (1984) Population biology of Balanus trigonus on a subtidal rocky outcrop near Beaufort, North Carolina. J Elisha Mitchell Sci Soc 100:1-11

Wilson HV (1902) The sponges collected in Porto Rico in 1899 by the U.S. Fish Commission Steamer Fish Hawk. Bull US Fish Comm 2:375-411

> Winston JE (1977) Distribution and ecology of estuarine ectoprocts: a critical review. Chesap Sci 18:34-57

Winston JE (2005) Re-description and revision of Smitt's 'Floridan Bryozoa' in the collection of the Museum of Comparative Zoology, Harvard University. Virginia Mus Nat Hist Mem 7:1-147

Winston JE (2009) Stability and change in the Indian River area bryozoan fauna over a twenty-four year period. Smithson Contrib Mar Sci 38:229-239

Winston JE, Hayward PJ (2012) The marine bryozoans of the northeast coast of the United States: Maine to Virginia. Virginia Mus Nat Hist Mem 11:1-180

Witman JD, Roy K (2009) Marine macroecology. The University of Chicago Press, Chicago, IL

Woods Hole Oceanographic Institution (1952) Marine fouling and its prevention. US Naval Institute, Annapolis, $\mathrm{MD}$

Zullo VA (1964) Subclass Cirripedia. In: Smith RI (ed) Keys to marine invertebrates of the Woods Hole region. Contribution No. 11, Marine Biological Laboratory, Woods Hole, MA, p 89-92

Zullo VA (1966) Thoracic cirripedia from the continental shelf off South Carolina, U.S.A. Crustaceana 11:229-244

Zullo VA (1979) Marine flora and fauna of the northeastern United States: Arthropoda: Cirripedia. NOAA Tech Rep NMFS Circ 425:1-29

Submitted: January 4, 2012; Accepted: April 16, 2012

Proofs received from author(s): June 21, 2012 